\title{
ПРИНЦИПИ АДМНІНСТРАТИВНО-ПРАВОВОГО ЗАБЕЗПЕЧЕННЯ ВЛАСНОЇ БЕЗПЕКИ В ОРГАНАХ ПОЛІЦІї
}

Вербицький О. Д.

Стаття присвячена розгляду принципів гарантування власної безпеки в органах поліції. Підкреслюється недостатня визначеність у законодавстві України принципів таких правовідносин. Встановлено наявність загальних системних закономірностей між принципами власного убезпечення в органах поліціі, що діють у різних галузях права. У контексті цього дослідження детально розглянуто спеціальні принципи адміністративно-правового гарантування власної безпеки в органах поліціі.

Ключові слова: адміністративно-правове забезпечення, власна безпека, принципи, поліцейський, поліція.

Статья посвящена рассмотрению принципов обеспечения собственной безопасности в органах полиции. Подчеркивается недостаточная определенность в законодательстве Украины принципов таких правоотношений. Установлено наличие общих системных закономерностей между принципами обеспечения собственной безопасности в органах полиции, действующих в различных отраслях права. В контексте данного исследования особое внимание уделено специальным принципам административно-пра вового обеспечения собственной безопасности в органах полиции.

Ключевые слова: административно-правовое обеспечение, собственная безопасность, принципы, полицейский, полиция.

Verbytskyi O. D. Consideration of the principles of ensuring one's own security in the police

The article is devoted to the consideration of the principles of ensuring one's own security in the police. The insufficient certainty in the legislation of Ukraine of the principles of such legal relations is emphasized. The purpose of the article is to formulate a holistic view of the principles of ensuring their own safety in the police. The article consistently reveals the importance of these principles for ensuring one's own security in the police. Depending on the criterion, the content is revealed and these principles are divided into: general social (which reflect economic, ideological, political patterns of public life, and which embody progressive philosophical and legal ideas of coexistence of state, society, individual, lay the foundations for the development of others specifically - legal principles) and special legal (which allow to distinguish the law from the whole set of social regulators, to determine its differences and features). In turn, in the set of special legal principles there are basic (guiding), specific functional and specific principles. The author highlights and analyzes a number of guidelines that determine the priority principles of ensuring their own safety in the police. In addition, in the context of this study, special attention was paid to special principles of administrative and legal security of their own security in the police: such as: professional competence of the subjects of their own security in the police; discretion of powers of authorized bodies (officials); planning and sequence of preventive, preventive and control measures in this area of administrative activity; a scientific approach in determining the strategy

(с) Вербицький О. Д., 2020 and tactics of action in the event of a threat to life, health or property of police personnel; coordination; collection of statistical information, monitoring and analysis of trends, problems and reasons for the existence of threats to their own security in the police, etc.

Key words: administrative and legal ensuring, own security, principles, police officer, police.

Постановка проблеми та їі актуальність. У преамбулі Декларації Ради Європи про поліцію (1979р.) згадується про те, що «у всіх державах поліція відіграє життєво важливу роль, вона змушена діяти в умовах, пов'язаних з ризиком для співробітників, і що виконання ними своїх обов'язків ще більше ускладнено, коли немає чітко визначених правил поведінки» [1]. Ці засади підкреслюють такі взаємопов'язані риси й умови функціонування поліції загалом та кожного окремого поліцейського, як підвищений ризик професії, нормативна врегульованість, активна підтримка суспільства. Даний напрям державної діяльності, який включає досить широкий спектр правовідносин, має ґрунтуватися на принципах, що зумовлює актуальність цієї статті.

Аналіз останніх досліджень і публікацій. У правовій науці до визначення принципів підходять по-різному: їх розглядають як найбільш загальні вимоги, що висуваються до суспільних відносин та їх учасників, характеризують як вихідні керівні засади, засадничі положення, що виражають сутність права і випливають з ідей справедливості та свободи, визначають загальну спрямованість і найістотніші риси чинної правової системи. Як слушно зауважує М.А. Вороніна, провідна роль принципів забезпечується їх прямим чи непрямим закріпленням у нормах права. Водночас принципи стають орієнтиром правотворчої і правозастосовної діяльності органів держави, беззаперечною вимогою до цієї діяльності [2, с. 197-198]. Ю.Д. Притика обґрунтовано підкреслює прикладне значення принципів, оскільки вони $\epsilon$ «наріжним каменем побудови будь-якого правового механізму розв'язання правових конфліктів» [3, с. 87]. А.М. Колодій до найсуттєвіших ознак принципів відносить насамперед їхню регулятивність. Такий характер притаманний як безпосередньо нормам-принципам, так і принципам, які виводяться з норм [4, с. 43]. Крім зазначеного, з'ясуванню властивостей та систематизації принципів адміністративно-правового забезпечення допомогли публікації М.Ю. Веселова [5, с. 190-193], А.О. Шишка [6, с. 74]. Водночас варто зазначити, що попереднє ознайомлення 3 нормативною базою за темою нашого дослідження вказує на неналежну визначеність у законодавстві принципів гарантування власної безпеки в органах поліції.

Метою статті $\epsilon$ формулювання на підставі узагальнення наявних у теорії права знань цілісного уявлення 
про принципи гарантування власної безпеки в органах поліції.

Виклад основного матеріалу. Значення принципів гарантування власної безпеки в органах поліції зумовлюється тим, що вони: а) мають властивість вищої імперативності, загальності, універсальності, значущості у правовідносинах щодо гарантування власної безпеки в органах поліції, їм притаманні стійкість і стабільність протягом невизначено тривалого часу; б) спрямовують розвиток і функціонування всієї системи гарантування власної безпеки в органах поліції; в) зумовлюють напрями правотворчої, правозастосовної діяльності й інших неправових форм адміністрування (маються на увазі організаційні та матеріально-технічні) у цій сфері державного управління; г) виступають найважливішим критерієм меж владних повноважень суб'єктів гарантування власної безпеки в органах поліції, а також індикатором законності дій учасників цих правовідносин; ґ) сприяють заповненню прогалин у правовому регулюванні зазначеного виду адміністративно-правової діяльності, тобто під час правозастосування, у разі спостерігання нормативного «вакууму», уповноважені суб'єкти мають діяти з дотриманням загальних принципів чинного права, основних прав і свобод людини, а також пріоритету законних інтересів поліцейських чи їхніх близьких родичів і членів сім'ї; д) забезпечують підвищення рівня правосвідомості в суспільстві.

Такі принципи закріплені у правових актах різного рівня: міжнародно-правових (наприклад, згадані вище засади, окреслені в Декларації про поліцію); законодавчих (наприклад, ст. 4 Закону України «Про оперативно-розшукову діяльність» визначає принципи такої діяльності, з якою пов'язана значна частина заходів гарантування власної безпеки в органах поліції); підзаконних, зокрема у відомчих тощо (наприклад, у п. 12 Положення про ДВБ (затвердженого наказом Національної поліції України від 9 листопада 2015 р. № 83) зазначено, що діяльність цього Департаменту ґрунтується на принципах верховенства права, дотримання прав і свобод людини, законності, відкритості та прозорості, політичної нейтральності, взаємодії з населенням на засадах партнерства, а також безперервності). Крім того, пояснення щодо правильного їх розуміння й урахування у правозастосовній діяльності можуть знаходити місце в рішеннях і узагальненнях міжнародних чи національних судових органів.

За змістом принципи можуть бути загальносоціальними (у них відображаються економічні, ідеологічні, політичні закономірності суспільного життя) і спеціально-юридичними. Так, у Декларації Ради Європи про поліцію (1979р.) наголошено, що поліцейський має право на підвищену заробітну плату з урахуванням особливих чинників несення служби, як-от підвищений ризик і ненормований робочий графік (п. 5 розд. «В»). Це, так би мовити, приклад, у якому відображено соціально-економічні закономірності суспільного життя поліцейських, які також опосередковано стосуються деяких аспектів їхньої власної безпеки. У Законі України «Про Національну поліцію» серед принципів їі діяльності закріплено політичну нейтральність цього центрального органу виконавчої влади. Це стосується незалежності діяльності поліції від рішень, заяв чи позицій політичних партій та громадських об'єднань. Поліцейські зобов'язані забезпечувати захист прав та свобод будь-якої людини незалежно від їі політичних переконань та партійної належності. Натомість держава і суспільство також повинні гарантувати безпеку та недоторканість таких поліцейських від будь-якого прямого чи заанґажованого політичного переслідування або тиску з боку політичних опонентів. Наприклад, серед засад та гарантій адвокатської діяльності $\epsilon$ такий принцип: «забороняється ототожнення адвоката із клієнтом» (п. 16 ч. 1 ст. 23 Закону України «Про адвокатуру та адвокатську діяльність»). Органам та посадовим особам поліції також іноді доводиться виконувати свої основні завдання за несприятливих або невизначених політичних обставин. Головне в таких ситуація діяти за принципом неупередженості та верховенства прав людини. Декларація Ради Європи про поліцію (1979 р.) визначає, що поліцейський повинен продовжувати виконувати свої завдання щодо захисту громадян і власності під час війни і ворожої окупації в інтересах цивільного населення. У період окупації і після іï закінчення жодні каральні або дисциплінарні санкції не можуть бути накладені на поліцейського, який сумлінно виконав вказівки влади, яка вважалася на той час законною, і коли виконання таких вказівок входило до обов'язків цього поліцейського. Сторона, що здійснила окупацію, також не повинна притягувати поліцейських до дисциплінарної або судової відповідальності через те, що вони виконували накази, які були віддані законною владою, до окупації [1].

Крім наведених прикладів, до загальносоціальних принципів наука відносить принципи гуманізму, демократизму, які втілюють прогресивні філософсько-правові ідеї співіснування держави, суспільства, окремого індивідуума, закладають підвалини розвитку інших спеціально-правових принципів. Принципи права, які відображені в конкретних нормах права, можна віднести до спеціально-юридичних. Саме ці принципи дозволяють виділити право з усієї сукупності соціальних регуляторів, визначити його особливості [7, с. 6].

За сферою дії принципи права поділяють на загальні (загальноправові), міжгалузеві, галузеві та принципи окремих правових інститутів. Даний підхід $\epsilon$ цілком прийнятним і для поділу за вказаним критерієм принципів гарантування власної безпеки в органах поліції. Таке забезпечення загалом має риси, які властиві будьякій правовій діяльності, тому загальні принципи (верховенства права, законності, рівності громадян перед законом тощо) так само $є$ вихідними засадами для правового регулювання та правозастосування в цій сфері правових відносин. Гарантування власної безпеки в органах поліції має міжгалузевий комплексний характер, тому в окремих проявах цієї діяльності доречно згадувати про принципи, які діють в окремих галузях права (галузеві) або актуальні для декількох галузей права водночас (міжгалузеві).

Так, за сферою суспільних відносин, на які поширюються принципи, та характером їх регулювання можна виділити принципи гарантування власної безпеки в органах поліції, які діють: а) у кримінально-правових відносинах: принцип відповідальності особи за вчинення суспільно небезпечного діяння, що передбачене законом як злочин (за погрозу або насильство щодо працівника правоохоронного органу тощо); принцип невідворотності кримінальної відповідальності; принцип презумпції невинуватості тощо; б) у цивільно-правових 
відносинах (так, зміст принципу неприпустимості свавільного втручання у сферу особистого життя людини (зокрема поліцейського) передбачає можливість такого втручання лише у визначених законом випадках); в) в адміністративно-правових відносинах.

У результаті розгляду принципів ювенальної юстиції в системі спеціальних принципів, які створюють відповідний правовий режим цієї діяльності, М.Ю. Веселов виокремлює: основні (керівні) (становлять вихідні ідеї конкретного виду діяльності, які мають більш орієнтуюче значення); конкретно-функціональні (поєднають вихідні засади, актуальні для окремих напрямів чи форм здійснення певної діяльності); специфічні принципи (визначають функціонування особливих (нестандартних чи пробаційних) проявів діяльності) [8, с. 44-45].

На наше переконання, серед важливих засад гарантування власної безпеки в органах поліції мають посісти місце такі керівні принципи, як:

гарантування державою посиленої охорони поліцейських від будь-яких загроз (як зумовлених виконанням цими працівниками службових обов'язків, так і тux, що не пов'язані з їх виконанням). Як і будь-який громадянин, співробітник поліції має право на захист свого життя та здоров'я від протиправних посягань. Водночас варто підкреслити, що призначення на посаду поліцейського передбачає конкурсний добір кандидатів, професійну підготовку (перепідготовку, підвищення кваліфікації) таких осіб, що забезпечує професійне виконання повноважень поліції на тій чи іншій посаді. Тому посилена охорона особового складу від будь-яких негативних чинників опосередковано виступає складовою частиною підтримання безперервної здатності органу поліції ефективно виконувати покладені на поліцію завдання;

гарантування державного захисту поліцейських, їхніх близьких родичів і членів сім'ї, майна цих осіб від будь-яких загроз, зумовлених виконанням цими поліцейськими службових обов'язків. Правове гарантування та державний захист власної безпеки поліцейських, їхнього найближчого оточення $\epsilon$ умовою професійного та неупередженого виконання ними своїх функцій без будь-якого стороннього впливу. Під час ухвалення рішень поліцейський має бути переконаний у безпеці власного життя, здоров'я, майнових прав, а також у безпеці життя, здоров'я, дотримання інших прав та інтересів своїх близьких родичів і членів сім’ї як у реальному часі, так і в майбутньому;

реагування на факти протиправного перешкоджання службовим особам полічії у виконанні покладених на них завдань та повноважень. Цей принцип можна назвати окремим утіленням принципу законності діяльності поліції в частині того, що поліцейському заборонено виконувати злочинні чи явно незаконні розпорядження та накази. У свою чергу, на виконання цього принципу мають існувати дієві механізми виявлення та належного правового реагування на такі факти, а посадові особи поліції повинні мати правові гарантії захищеності від будь-якого зовнішнього тиску чи подальшого переслідування;

- безперервність гарантування власної безпеки в органах поліції. Цей принцип гарантує, що кожен поліцейський (і навіть колишні співробітники поліції (міліції)) має право в будь-який час звернутися по допомогу щодо його убезпечення чи його близьких родичів і членів сім'ї. Цей принцип стосується постійного забезпечення й інших елементів власної безпеки в органах поліції, зокрема конфіденційності службової інформації тощо. Так, серед основних принципів роботи чергової служби органів (підрозділів) Національної поліції згадується про безперервний режим роботи, постійну готовність, а до завдань належить контроль за станом охорони адміністративних будинків поліції; забезпечення збереження табельної вогнепальної зброї та іншого озброєння, спеціальних засобів, засобів індивідуального захисту, зв'язку, оперативної та криміналістичної техніки, службової документації та іншого майна, що зберігається у спеціально обладнаних приміщеннях чергової служби (п. п. 4 та 7 наказу Міністерства внутрішніх справ України від 23 травня 2017 р. № 440);

превентивна спрямованість гарантування власної безпеки в органах поліції. Зазначена діяльність повинна базуватися на прогнозуванні ризиків, завчасному виявленні загроз (зокрема, на підставі конфіденційних і анонімних заяв, даних, отриманих оперативним шляхом) для охоронюваних законом інтересів, які утворюють зміст власної безпеки в органах поліції, та вжиття заходів щодо їх недопущення або своєчасного припинення. Тобто гарантування власної безпеки в органах поліції має бути передусім зорієнтовано на недопущення неправомірних дій стосовно поліцейських (їхніх близьких родичів і членів сім'ї, майна цих осіб), а не реагування на їхні негативні наслідки;

виявлення й усунення чинників, які негативно впливають на діяльність поліції. Цю керівну засаду зумовлює необхідність розуміння природи загроз власній безпеці в органах поліції та характерних причин і умов їх виникнення, що дозволяє ефективніше діяти для запобігання таким або нейтралізації негативних ефектів. Серед таких чинників можуть бути як поведінка окремих фізичних осіб, так і неправомірні офіційні чи неофіційні команди (рішення) або дії посадовців. Наведений принцип об'єктивується через поєднання науково-аналітичної діяльності із практикою застосування правових, організаційних, профілактичних, контрольних заходів;

однакове ставлення до кожного поліцейського, його близького оточення, без будь-якої дискримінації. Цей принцип підкреслює однакову цінність кожного поліцейського незалежно від його посади, колишніх заслуг, особистих якостей;

поєднання заходів кримінально-, адміністративно-правового характеру, оперативно-розшукових та матеріально-технічних заходів під час гарантування власної безпеки в органах поліції. Цей принцип продиктований комплексністю зазначеного виду діяльності. Казати однозначно про те, який саме характер заходів має переважати в гарантуванні власної безпеки в органах поліції, штучно прив'язувати до тієї чи іншої галузі права, видається нам не зовсім коректним. Правильнішим буде говорити про ті чи інші галузеві аспекти забезпечення їх реалізації. Практичний результат буде мати місце лише в поєднанні чи послідовному чергуванні зазначених заходів залежно від обставин.

До конкретно-функціональних (спеціальні) принципів гарантування власної безпеки в органах поліції доречно віднести: а) запровадження та підтримання пропускного та внутрішньооб'єктового режиму 


\section{Правове забезпечення адміністративної реформи}

в органах та підрозділах поліції; б) захист персональних даних в органах поліції; в) встановлення та дотримання в органах поліції режиму секретноcmi (єдиний порядок забезпечення охорони державної таємниці); г) принцип професійної дидактики поліцейських (узагалі цей принци пов' язують із базовим навчанням рядових співробітників, що включає психологічні й етичні аспекти професійної діяльності поліцейських) [9, с. 2] (уважаємо, що сферу його дії варто доповнити і готовністю, психологічною, тактичною та фізичною, поліцейських до ймовірних (прихованих) чи реальних загроз, що можуть виникати у зв'язку з їхньою професійною діяльністю); ґ) інформування підлеглими поліцейськими безпосереднього керівника про обставини, що унеможливлюють їх подальшу службу в поліціі або перебування на займаній посаді; д) реагування на кожне звернення чи оперативну інформацію щодо наявності загрози власній безпеці поліцейського чи органу поліції; е) облік та перевірка всіх фактів протиправного впливу на законну діяльність поліцейського; є) облік і аналіз усіх надзвичайних подій за участю поліцейських, а також їхніх близьких родичів і членів сім'ї; ж) чітка процедура проведення службових розслідувань (перевірок) в органах поліції щодо подій за участю особового складу; з) встановлення права поліцейського застосовувати фізичну силу, спеціальні засоби та вогнепальну зброю для відбиття нападу на поліцейського або членів його сім'ї, у разі загрози їхньому життю чи здоров'ю; i) правове закріплення інституту державного захисту працівників правоохоронних органів (у частині вжиття особливих заходів щодо працівників поліції, їхніх близьких родичів, членів сім'ї) тощо.

3 огляду на предмет нашого дослідження, на детальну увагу заслуговують спеціальні принципи адміністративно-правового гарантування власної безпеки в органах поліції. В одній із публікацій М.Ю. Веселова дається визначення принципів адміністративно-правового забезпечення (на прикладі функціонування та розвитку ювенальної юстиції) [5, с. 190-193]. За аналогією можна припустити, що принципами адміністративно-правового гарантування власної безпеки в органах поліції $\epsilon$ закріплені в адміністративно-правових нормах основоположні засади, керівні ідеї, що відбивають сутність і специфіку публічного адміністрування та деякі прояви оперативної діяльності у вказаній сфері правовідносин. До таких принципів можна віднести: a) професійну компетентність суб'єктів гарантування власної безпеки в органах поліції; б) дискреційність повноважень уповноважених органів (посадових осіб) суб'єктів гарантування власної безпеки в органах поліції, з урахуванням різних правових, організаційних i оперативно-технічних заходів за всіма напрямами цієі діяльності; в) плановість та послідовність профілактичних, превентивних та контрольних заходів у цій сфері адміністративної діяльності; г) науковий підхід у визначенні стратегії та тактики дій у разі наявності загрози життю, здоров'ю, житлу і майну осіб, які підлягають захисту, а також інших службових інтересів поліції, з урахуванням рівня розвитку суспільних відносин та світової практики гарантування власної безпеки в органах поліції; ґ) злагодженість - адміністративно-правові відносини $\epsilon$ фактично тим умовним середовищем, на ріні якого відбувається узгодженість основних та додаткових (проміжних) рішень і дій різних уповноважених суб'єктів, поєднання правових та «неправових» (соціальні, психологічні тощо) форм гарантування власної безпеки в органах поліції; д) збір статистичної інформації, моніторинг і аналіз тенденцій, проблем і причин існування загроз власній безпеці в органах поліції тощо.

Висновки. Натепер далеко не всі наведені принципи власної безпеки в органах поліції знаходять належне правове визначення (а лише за таких умов вони здобувають характеру загальних правил поведінки, інакше - залишаються ідеями-принципами, які не мають риси обов'язковості - О. В.), деякі закріплені тільки на рівні підзаконних нормативно-правових актів. До того ж відсутність єдиного нормативного акта, який би визначав організаційно-правові засади у сфері гарантування власної безпеки в органах поліції ускладнює цілісне сприйняття системи таких принципів.

У підсумку варто зазначити, що сформульоване в цій статті бачення системи принципів у перспективі має бути втілено в нормах Закону України «Про Національну поліцію», а також у проєкті закону «Про органи внутрішніх справ». Реалізація цих принципів має бути деталізацована на рівні підзаконних нормативно-правових актів (відомчі та міжвідомчі), що окреслює перспективи наших подальших наукових розвідок.

\section{Література}

1. Декларація про поліцію : резолюція Парламентської асамблеї Ради Європи від 8 травня 1979 р. № 690 (1979). Поточна редакція. URL: https://zakon.rada.gov.ua/laws/ show/994_803 (дата звернення: 21.09.2019).

2. Загальна теорія держави і права : підручник для студентів юрид. ВН3 / М.В. Цвік та ін. ; за ред. М.В. Цвіка, О.В. Петришина. Харків : Право, 2009. 584 с.

3. Притика Ю.Д. Зміст та класифікація принципів медіації. Бюлетень Міністерства юстиції України. 2010. № 10. С. 86-92.

4. Колодій А.М. Принципи права: генеза, поняття, класифікація та реалізація. Альманах права. 2012. Вип. 3. С. 42-46. URL: http://dspace.nbuv.gov.ua/bitstream/ handle/123456789/63807/08-Kolodiy.pdf (дата звернення: 31.08.2019).

5. Веселов М.Ю. Принципи адміністративно-правового забезпечення функціонування та розвитку ювенальної юстиції. Проблеми законності. 2019. Вип. 147. С. 187-196. DOI: $10.21564 / 2414-990 x .147 .178179$.

6. Шишко А.О. Адміністративно-правові засади забезпечення особистої безпеки працівників суду в Україні : дис. ... канд. юрид. наук: 12.00.07. Львів, 2010. 229 с.

7. Баранов О.А. Система принципів інформаційного права. Правова інформатика. 2006. № 2 (10). С. 5-15. URL: http://ippi.org.ua/sites/default/files/06bopip.pdf (дата звернення: 30.09.2019).

8. Веселов Н.Ю. Систематизация принципов функционирования и развития ювенальной юстиции. Труды Академии Министерства внутренних дел Республики Таджикистан. 2019. № 4 (44). С. 38-47.

9. Реформування поліції: міжнародний досвід : інформаційна довідка, підготовлена Європейським інформаційно-дослідницьким центром на запит народного депутата України. Київ. 17 с. URL: http://euinfocenter.rada.gov.ua/ uploads/documents/29325.pdf (дата звернення: 05.10.2019).

Вербицький О. Д., aсnірант аспірантури Одеського державного університету внутрішніх справ 